\title{
'Rabbit Hutches on Postage Stamps': Planning, Development and Political Economy
}

\author{
Alan W. Evans \\ [Paper received in final form, April 1991]
}

\begin{abstract}
Summary. The supply of land for housing has been restricted by planning controls. The prices of land and of houses have risen in consequence. As a result land has been used with increasing intensity with infill, 'town cramming' and smaller houses on less land-'rabbit hutches on postage stamps'; a destruction of the urban environment of the many to preserve a rural environment for $a$ few. Why is the supply of land restricted? Firstly, it is suggested, because the British misapprehend the degree of urbanisation in their own country. Secondly, because rural and farming interests ensure that the planning system operates in their favour. And thirdly, and most importantly, because the planning process is tilted in favour of the existing residents of an area who seek to preserve their environment by resisting intruders. $A$ number of suggestions are made to resolve the situation by increasing the supply of land or reducing the demand for land.
\end{abstract}

\section{Introduction}

Some early work of mine looked at aspects of the economics of town planning. One of the results of that research was a study of the economic effects of 'green belts'. It was shown that there could be substantial economic costs-journeys to work could be longer than they otherwise would be and the cost of housing in a city surrounded by a green belt could be higher than it otherwise would be. These costs were usually ignored but needed to be taken into account when deciding whether the benefits of green belts outweighed their costs (Evans, 1973, ch. 15; 1985, ch. 12; House of Commons, 1983).

This work was done some time ago but more recently $I$ have started to look again at the economic effects of restrictions on land availability for development, not just with respect to green belts, but where, as in southern England, development is restricted over the whole region. This work has been published both by the Housebuilders Federation and as an Institute of Economic Affairs Occasional Paper called No Room! No Room! (Evans, 1987, 1988). When I was invited to deliver the Denman Lecture I was asked to develop these ideas further.

\section{The Effects of Restrictions on Land Availability}

First we have to set the scene. For those unaware of the ideas which were put forward in these earlier publications we have to review the empirical evidence as to 
the effects of restrictions on the availability of land for development on the pattern of residential development and the cost of housing.

The first and most essential fact to note is the difference between the price of land in the South East when this land is in agricultural use, and its price with planning permission for residential development. The price of land in agricultural use in the vicinity of Reading is of the order of $£ 2000$ per acre, but with permission for residential development the price can rise to between $£ 500000$ and $£ 1 \mathrm{~m}$ per acre. The price might have been even higher one or two years ago but land prices have fallen because of the depression in the housing market. Nevertheless there is even now a substantial difference between the two prices which has to be explained. Elsewhere in the country the prices of agricultural and residential land also differ substantially but the absolute differences are not quite as great.

Why should there be this substantial difference between the price of land with planning permission for development and its price in agricultural use? The answer is that since planning controls were instituted in the late 1940s there has been a substantial increase in the demand for land for housing whilst the supply of land for development has not increased at anything like the same rate.

The demand for land for housing has increased for several reasons. The first and most obvious reason is that the population of the country has increased, so that the number of people needing to be housed has increased. The second reason is that this population has been distributed amongst smaller households. We have a larger number of old age pensioners or younger people setting up house, and we have a larger number of single-parent households. Thus even if the population had remained the same a larger number of dwellings would have had to have been built. The third reason is that incomes have increased substantially since 1947 and with increas- ing incomes people want larger houses. They want more space and, in some parts of the country, they want second homes. The fourth reason can be found in the transport improvements that have occurred over the last 40 years. Car ownership has become widespread and people have been able to move away from the cities, away from the high densities which they had to occupy, often in slum areas in the inner cities, when they had to live close to their work-places and when these work-places were also concentrated in the inner cities. In the postwar era they have been able to move out to new towns and other settlements outside the large cities. The fifth reason can be found in the tax advantages of owneroccupation. These tax advantages reduce the cost of housing to those who can afford to buy. As a result, and also because of rent controls, over the past 40 years the proportion of the population renting from a private landlord has fallen dramatically and the proportion owning has increased. Because the cost of housing is cheaper for those who own their own homes these tax advantages have also encouraged people to attempt to buy more housing than they would have done if they had rented.

On the supply side the situation has been different. Certainly it is true that back in the 1940s undeveloped land was zoned for residential development in anticipation of an increased number of dwellings. It was planned that there should be decentralisation from the cities, that there should be slum clearance and that people should move to new towns. But the increase in the demand for housing for other reasons, in particular the increase in the size of the homes which would be wanted by people because of economic growth, was not anticipated and by the 1960s most of the land which had been zoned for housing had been developed. Local authorities became increasingly unwilling to zone nonurban land, i.e. rural land, for development. Moreover as the supply began to run out developers had to scavenge for sites, desperate to find somewhere, anywhere, 
where they thought they could obtain permission to develop. So by the early 1980 s about a third of sites for residential development in southern England were found by developers, usually within the boundaries of existing urban areas-sites which had not actually been identified by planners beforehand as being suitable for development.

This disparity between demand and supply had certain consequences in the way in which housing was developed, which I shall now examine. Firstly, both house and land prices rose considerably faster than retail prices or incomes. This is made clear in Figure 1, which shows indices of the average price of new dwellings and housing land, incomes in the South East (outside Greater London) and also the national retail price index. In each case the index for 1969 is set equal to 100 . The figure shows that whilst retail prices rose from approximately 80 in 1963 to about 660 in 1989 , land prices over the same period rose from about 50 to about 3000 . So whilst retail prices increased eightfold land prices increased 60 -fold. At the same time incomes and house prices rose somewhat faster than retail prices, as one would expect with a rising standard of living, but rather more slowly than land prices.

What then happened was that because of rising house and land prices people tended to trade down, buying smaller houses than they otherwise would have done. This can be seen from Table 1. The left-hand column is an index of an average cost of housing in the South East, i.e. the average of what people actually spent. This rose about fivefold from about 1975 through to about 1989. It is this index which is indicated by the white squares in Figure 1 showing the average price of new dwellings, which rises in line with incomes. The right-hand column of Table 1 is an index of house prices which is weighted in that it is based on the assumption that people buy the same types of house in the same proportions in each year. In other words it is constructed in the same way as a retail price index. The weighted index shows that house prices rose rather faster than is indicated by the unweighted index in the first column. The weighted index rose from 100 to 691 over the 14-year period whilst the unweighted index rose from 100 to 557. Thus as house prices rose, people traded down by buying somewhat smaller properties, although the amount that they spent on these smaller properties rose in line with their incomes.

Table 1. Weighted and unweighted house price indices, South East (ex. Greater London) $(1975=100)$

\begin{tabular}{ccc}
\hline Year & Unweighted & Weighted \\
\hline 1975 & 100 & 100 \\
1976 & 106 & 107 \\
1977 & 112 & 114 \\
1978 & 129 & 133 \\
1979 & 168 & 177 \\
1980 & 203 & 214 \\
1981 & 204 & 224 \\
1982 & 202 & 226 \\
1983 & 230 & 256 \\
1984 & 255 & 290 \\
1985 & 276 & 320 \\
1986 & 331 & 378 \\
1987 & 391 & 461 \\
1988 & 495 & 598 \\
1989 & 557 & 691 \\
\hline
\end{tabular}

Source: Housing and Construction Statistics; Family Expenditure Survey; Economic Trends.

Because land prices had risen there was considerable pressure to use urban land intensively and this has further consequences as it affected the way that people behaved. Firstly, people discovered that, if they could get planning permission, their back gardens were worth a lot of money and so in many cases these back gardens were sold off for development. Typically people sold them off at the time that they moved away so that whilst they were unwilling to sell at the time they were living in the house they were willing to at the time that they left. Moving allowed NIMBY - Not In My Back Yard-to be replaced by BIMBY - a Bungalow In My Back Yard. 


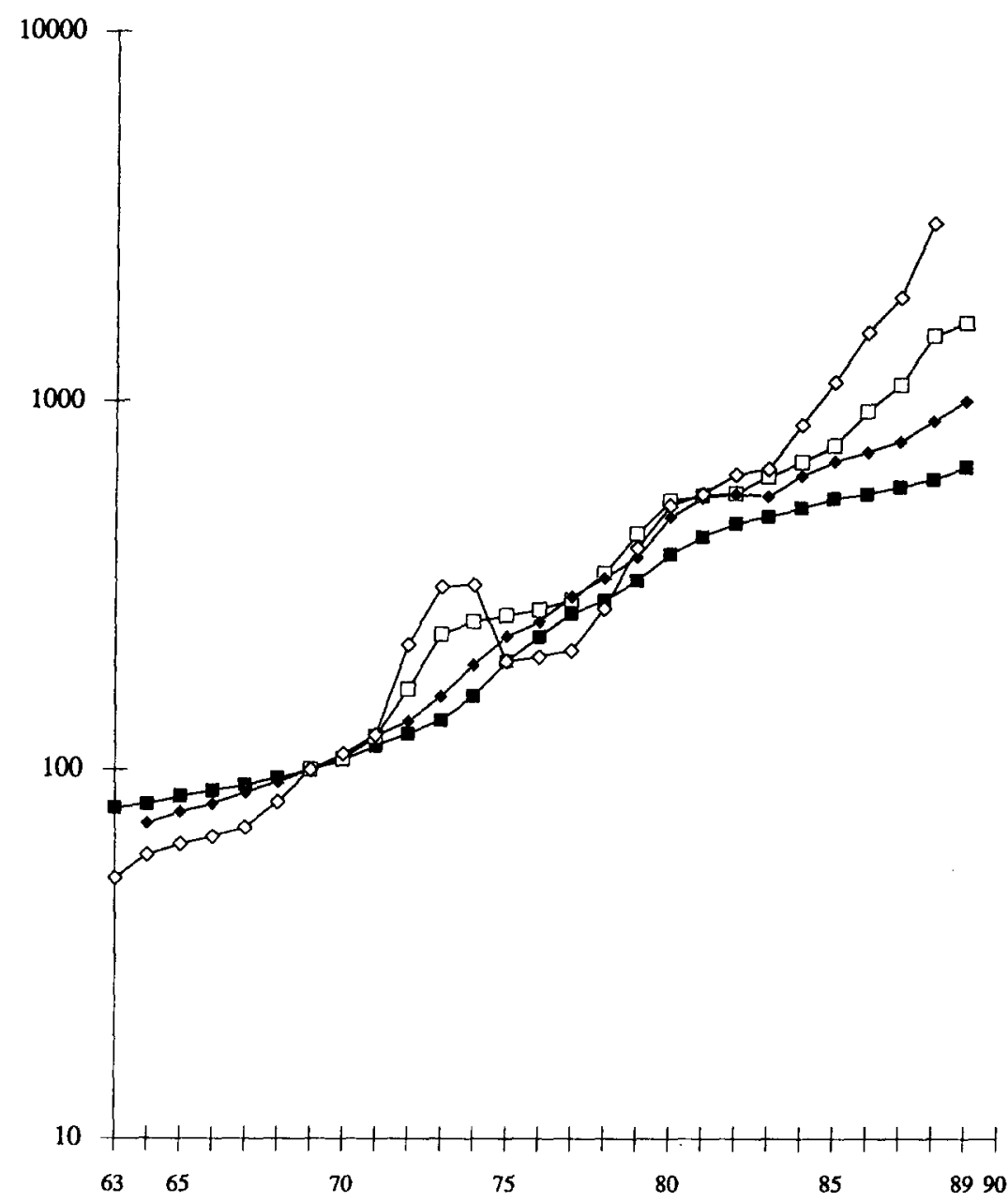

Figure 1. New house prices $(\square)$, housing land prices $(\diamond)$ and incomes $(\diamond)$ in the South East (outside Greater London) and retail prices (national) (ם). Source: Housing and Construction Statistics; Family Expenditure Survey; Economic Trends.

Secondly, whilst higher incomes meant that people wanted larger houses, housing land had become increasingly expensive so that the way in which houses were constructed changed. Michael Ball found that the square footage, the internal area of houses, seemed not to have increased over time but that the average number of rooms in the house had increased (Ball, 1983). People got larger houses in terms of the number of rooms but they got more or less the same size of house on average, so that rooms in newer houses tended to be smaller. And, of course, they got a house with a smaller garden.
Thirdly, as mentioned earlier, in order to find sites for development, developers had to hunt them out. According to a study by Roger Tym \& Partners in the early 1980 s, about a quarter of the sites developed in the South East were found in this way (Roger Tym \& Partners, 1987). The consequence was the infilling of the builtup area in towns and villages as developers sought out small sites-sports grounds, back gardens, allotments, houses with large gardens which could be demolished-anywhere where housing could be fitted in. In this way, it was quipped, 'town planning' had been replaced by 'town cramming'. 
Fourthly, as land became more expensive there was a gradual shift from constructing buildings which used a lot of land to constructing those which used land intensively. This is illustrated in Figure 2. This figure shows, for England and Wales, the types of dwellings provided in the private sector between 1969 and 1989. The vertical axis shows the percentages. Thus for each year there is a vertical column which represents 100 per cent of dwellings built in that year. Now it can be seen looking along the bottom of the figure that whilst bungalows accounted for 26 per cent of dwellings built in 1969 the number of bungalows has fallen steadily over the years to approximately 13 per cent of the total by 1989 . On the other hand, looking at the top of the figure, whilst only 3 per cent of dwellings built in the private sector in 1969 were flats and maisonettes, by 1989 the proportion had increased to nearly 17 per cent. In the same way it can be seen that the proportion of new houses which were terrace or town houses had also increased substantially. It might be argued that this was due to a demographic change. We know that the number of smaller households had increased and one would expect that smaller households would pre- fer smaller dwellings, such as flats, to detached houses and bungalows. Nevertheless other evidence indicates that this argument is wrong.

Figure 3 presents the first piece of evidence. This shows that bungalows have risen rather faster in price since 1969 than other types of dwelling. Indeed, Figure 3 appears to show that the larger the amount of land used per dwelling, the faster that kind of dwelling has risen in price. So bungalows have risen in price faster than detached houses for most of this period, and the price of these has in turn risen faster than the price of semi-detached houses; they in turn have risen in price faster than terrace housing, while flats have risen in price least of all. Now if there had been a shift in demand towards flats one would have expected the reverse to be true, i.e. flats would have risen in price faster than other types of dwelling. These price indices show that in fact the differences between the rates of price increase of the various types of dwelling seem to have been caused by the increase in land price, which has pushed up the price of dwellings that use a lot of land.

Table 2 presents a second piece of evidence. This table shows the variation

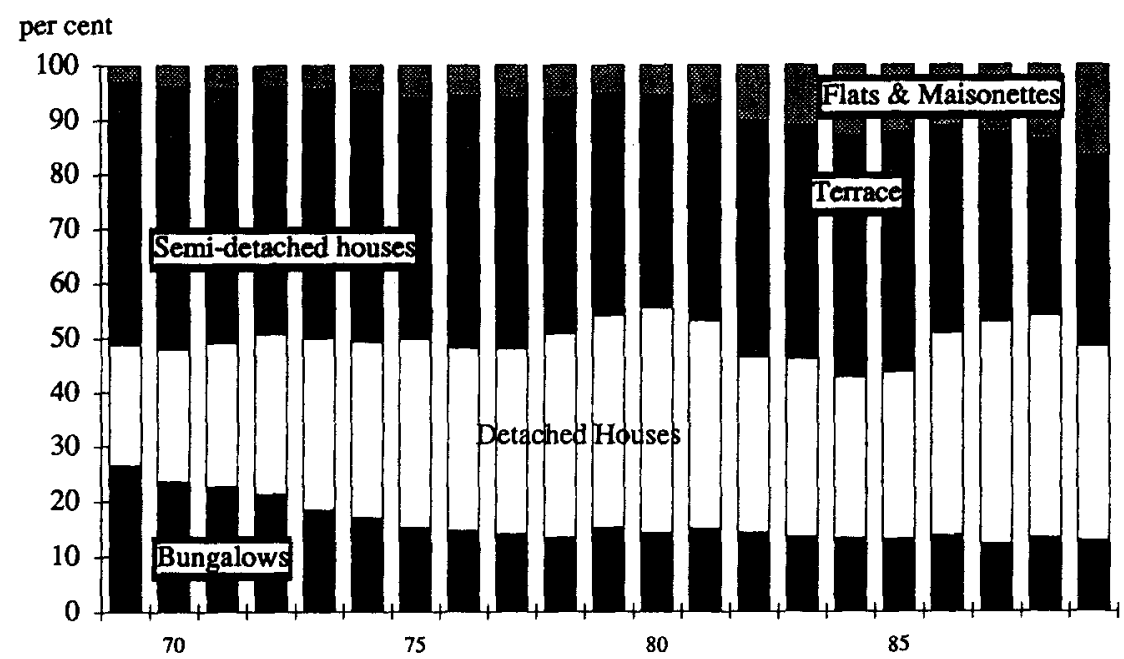

Figure 2. Distribution of different types of dwelling mortgaged. Source: Housing and Construction Statistics. 


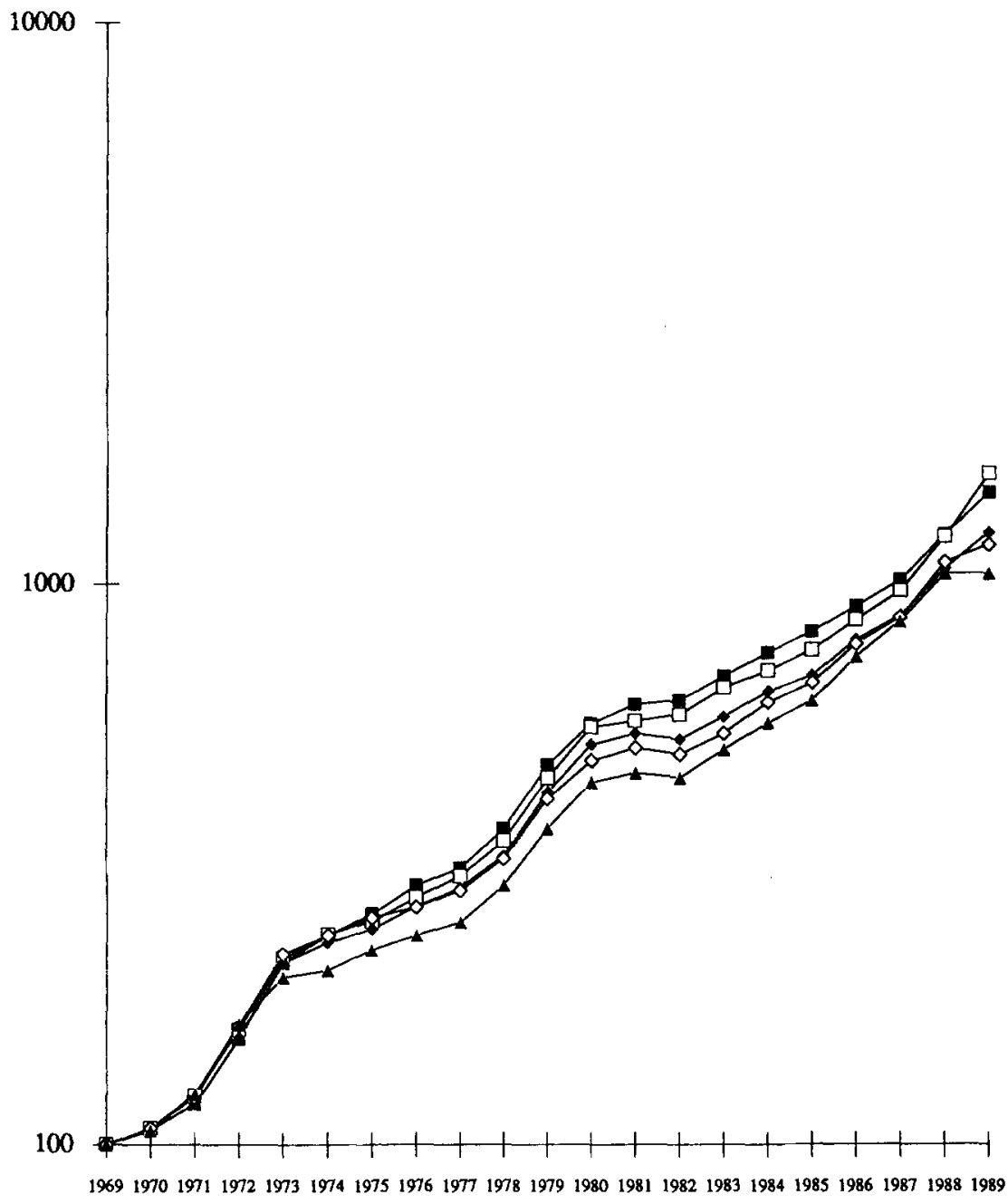

Figure 3. Dwelling price by type of dwelling mortgaged in the UK (1969=100): ( $\mathbb{0}$ ) bungalows; $(\square)$ detached; $(\diamond)$ semi-detached; $(\diamond)$ terrace; $(\Delta)$ flats and maisonettes. Source: Housing and Construction Statistics.

between regions in the types of dwelling on which building work was started in 1990 . The bottom line of the table shows that 67 per cent of dwellings started in Greater London were flats and maisonettes and that 22 per cent were terrace housing. Of course we should expect this. London is a major city and land will be used intensively. Yet if we look outside Greater London at the rest of the South East we find that 57 per cent of new dwellings were in the form of flats, maisonettes and terrace houses, even though this is a region in which there are no really large cities.
Now this intensity of development must be due to high land prices. It cannot be due to an increase in the demand for smaller dwellings because of demographic change. If it were due to demographic change we would expect the same pattern of development across the whole country. But the table shows that as we move outwards from the South East through the South West and East Anglia, the proportion of dwellings being built as flats, maisonettes and terrace houses declines until, in Yorkshire and Humberside, where land prices are the lowest in the country, only 26 per 
Table 2. Dwelling types started in 1990 , by region (percentage)

\begin{tabular}{lccccc}
\hline & \multicolumn{5}{c}{ House type } \\
\cline { 2 - 6 } & Bungalows & Detached & $\begin{array}{c}\text { Semi- } \\
\text { detached }\end{array}$ & Terrace & $\begin{array}{c}\text { Flats and } \\
\text { maisonettes }\end{array}$ \\
\hline North & 14 & 37 & 16 & 13 & 21 \\
North West & 10 & 45 & 20 & 10 & 15 \\
Yorkshire and Humberside & 20 & 38 & 17 & 12 & 14 \\
West Midlands & 7 & 38 & 18 & 21 & 16 \\
East Midlands & 10 & 41 & 25 & 16 & 8 \\
East Anglia & 11 & 34 & 17 & 27 & 12 \\
South West & 8 & 28 & 14 & 30 & 21 \\
South East (excluding & 5 & 27 & 12 & 25 & 32 \\
$\quad$ Greater London) & 3 & 4 & 5 & 22 & 67 \\
Greater London & & & & & \\
\hline
\end{tabular}

Source: National House-building Council (1990, table 6).

cent of new dwellings are flats, maisonettes and terrace houses. On the other hand 20 per cent of new dwellings in that region were built as bungalows, whilst only 5 per cent of new dwellings in the rest of the South East were bungalows. Now it seems clear that these regional differences could not be the result of any demographic shift, since this would have affected each region in the same way. The only explanation we are left with is that the regional differences result from an attempt to economise on land by building at a higher density in areas where land is more expensive.

\section{Visual Consequences}

This pattern of development has had certain visual consequences. These consequences were, I am sure, not intended by planners but have certainly resulted from the policies of preserving rural land and using urban land intensively. The first of these consequences is that there is a very visible edge to any urban development. On one side of the boundary we have green fields and on the other side we have a highdensity urban area. This effect is very noticeable in areas such as Lower Earley, on the southern edge of Reading, where new development has taken place at a very high density. As a result, as one travels south from the centre of Reading densities fall until they are at their lowest in areas developed in the 1950s; then they start to increase again as one passes through areas developed in the three succeeding decades.

Within those urban areas it is interesting to see the way in which developers have reacted to a combination of increasing incomes and rising land costs. People with higher incomes expect gardens and they expect their houses to be detached. Developers have tried to give people what they want but they have had to do so subject to the constraint imposed by the high cost of land. This results in certain design features, the explanation for which is not otherwise immediately obvious. For example, in some developments one sees the houses built close up against the road. The reason for this would appear to be that although it results in a very short front garden-one that may not even be a car's length, so that to get the car off the road the garage itself at the side of the house is 'recessed' away from the road-it still allows a back garden of a reasonable size, say one large enough for the children to play swingball.

Another design feature that one sees occasionally is the removal of the garage from its usual location next to the house. Sometimes it is removed some way, and all the garages related to a group of houses are 
put in a separate block. In one or two cases, however, one sees that the garage is a separate building placed in front of the house. When I first saw this kind of development I found it rather surprising-I could not see why anyone should want to sit in their front living room and look out at the back or side wall of their garage. But after a time $I$ realised that this design allowed the developer to build substantial houses which could be sold as detached. If the garages had been put adjacent to the houses in the normal way then, because of the width of the site and the size of the houses being built, all the houses would have had to have been adjacent to each other and connected. There would have been no gaps between the houses because there would have been no room for any. So houses which the developer wished to sell as substantial homes for high-income households would have been terrace houses or 'semis' at best, and the price the developer could have obtained would have been much reduced.

A third way of achieving the developer's desired objective of the maximum number of substantial detached houses within a restricted amount of land can be seen in the use of communal drives for a number of homes. This can appear quite attractive. Some of the area around which four or five houses are grouped is used jointly by the households as a communal driveway into their own separate garage spaces. The result is to economise on land because the space is being used jointly. If the area in front of each house is merely grassed and not fenced off, then the land area at the front of each house is reasonably spacious because this land is shared, visually at least, even if, in practice, only the driveway is actually shared physically. As I have argued, I regard this form of design as being an attempt to economise on space but it is worth repeating that it has often resulted in a rather attractive grouping of houses.

A further consequence of the high price of land has been a tendency for househol- ders to extend their homes. Families wishing to move to larger homes have looked around and found that any new houses which were being built seemed to have miniscule gardens and to be rather expensive. After searching for some time they have taken stock of the situation and said, "The garden of our existing house is larger than anything we have seen that we could afford. Could not we extend the house we live in now? Then we would get a larger house at a price we could afford and we would not even have to move!" Sometimes the process of extension is more deliberate. Having found nothing that they could afford of the size and with the garden space that they want, households may deliberately move into a house which is smaller than they feel they need but which has the right amount of land, then set out to extend the house to the size that they want. In this way many streets in outer London and the towns of the South East are gradually 'terraced' as each house is extended to fill the gap between it and the next.

\section{The Urban Environment}

The end result of all the trends described above has been the intensification of land use within existing urban areas and the elimination of any urban open space which is not in some way safeguarded. Houses are extended over their garden space and the ends of gardens are sold off, as are sports grounds 'surplus to requirements', garden nurseries, allotments and any other 'unused' pieces of land. As part of this process we also see the demolition of existing houses built at a low density and their replacement by flats or town houses to intensify further the density of urban development. In some cases this pressure has been so great as to lead to what can only be described as the destruction of the urban environment. In Harrow-on-the-Hill, identified as an Area of Special Character and almost wholly included within various Conservation Areas, it was recently calcu- 
lated that there were 22 construction sites on which 194 flats or houses were being developed and that, in addition, there were outstanding applications for planning permission for a further 376 dwellings (Harrow Observer, 1989).

The cause of this intense development pressure is the low density of development. This low density of development makes the area desirable as a place to live. But of course it also means that redevelopment to a higher density can be highly profitable, whilst, at the same time, it is of course the reason why most parts of the Hill have been designated as Conservation Areas.

The Council for the Protection of Rural England has fought successfully to prevent the development of land in rural areas. The consequence of this conservation of rural land has been pressure for the destruction of the few areas in England which are designated as urban Conservation Areas. It seems odd to preserve millions of acres unspoilt for the few and spoil the urban environment for the many. I have sometimes thought that as well as the Council for the Protection of Rural England there ought to be a rival organisation called, say, the Union for the Protection of Urban England.

Given that the policy seems to be that we should preserve rural areas and usually allow development only in urban areas the question arises as to why there should be such a policy. There seem to be three possible answers to this question which I shall try and deal with. Each of these answers is partially true but not the complete answer-each, I think, reinforces the other.

The three possible answers are, firstly, that, yes, it is what the British people want. People do believe that rural land should be preserved even if this is at the expense of higher densities of development. But I would argue that in some senses their information, the information on which they are basing this view, is incorrect and that this information is incorrect partly for the second reason-the policy is in the interests of various groups which might be called the agricultural and rural interests. But these interests would be too weak to restrict development in this way without what I would regard as the third and most important reason-the balance of political forces in the planning system reinforces the status quo by giving undue weight to the views of those who live in an area, particularly a rural area, and no weight at all to the views of those who might move into an area. We shall deal with these three answers in turn.

\section{The Public Interest}

If you discuss the pattern of development in this country with people, particularly those who are not involved in the analysis of the problem, you will often find that they have very strongly held beliefs that there is not enough land in the country for development, that there is a shortage of rural land and that therefore urban land should be developed as intensively as possible-the existing pattern of development is therefore thought regrettable but inevitable. Now the problem here is that the evidence shows that Britain is not as developed as everyone thinks. A classic study of land use in Britain by Robin Best published in the early 1980 s showed that at that time south-eastern England was 19 per cent urbanised and 81 per cent rural. I should anticipate, and my own experience confirms this, that if you talk to a Londoner he or she is more likely to believe the reverse to be true, that the South East was 81 per cent urban and 19 per cent rural. As an aside one might note that 19 per cent does not indicate a very high level of urbanisation. For example the whole of the former West Germany is only about 12 per cent urbanised (Best, 1981).

Even if people in the South East are willing to concede that there might be some room for further urban development in the region, they are then likely to argue that this development should be diverted to the North. The South, it is felt, is more 
highly urbanised than the North. Now the trouble with this argument is that the North West, which is 26 per cent urbanised, is in fact the most urbanised region in the country. Whilst the South East is, as I have indicated, 19 per cent urbanised, the main reason for this relatively high proportion is the existence of London at the centre of the region. As one moves outward from London, the outer South East and two regions bordering the South East-the South West and East Anglia-are relatively non-urbanised. It is therefore not clear why urban development should be steered away from the outer South East, the South West and East Anglia towards the northern regions, which are at least as urbanised if not more so.

Finally, even if it is conceded that there is room for urban development and that the regions in the South are not heavily urbanised relative to the more northerly regions, it is likely to be argued that controls are necessary to prevent development in the South because if controls were relaxed then the whole region would be urbanised. The hyperbolic cliche is that "the whole of the South East would be covered with tarmac". This argument has been effectively dealt with by my colleagues Paul Cheshire and Stephen Sheppard at the University of Reading. They showed, using a fairly sophisticated econometric model, that in the absence of inmigration if there were no controls in the South East the proportion of the area which was urbanised might in the very long run increase to about 28 per cent, so that the region would still be 72 per cent rural. Virtually all of this increase in the area would actually be an increase in garden space, and so would not be an increase in the area under housing except in the sense that land would be described as developed because it was included within people's gardens (Cheshire and Sheppard, 1989).

Now even if the evidence shows that the South East is not over-urbanised, the question arises as to why people believe this myth of new development; why do people believe, as many seem to, that the South East is more urban than rural? I have thought for some time about this to try to find a rational answer. In the end I seem to have come up with not one but five possible reasons.

The first reason is that most people, particularly Londoners, live in towns, do not often go out of towns and, if they do, tend to move between towns. What they see all the time, therefore, is an urban area. Indeed, as we have indicated it is rather difficult to see anything else. Because rural development is not generally allowed, people are, in effect, prevented from living in the country and therefore do not see very much of it in their everyday life. Since people live in towns and see urban areas all the time they believe that this is actually what the whole of the South East must be like.

The second reason is that, even if people get out of the cities and towns in which they live and work, the way in which transport routes are built means that they rarely get out of sight of urban areas. Roads and railways follow urban corridors because the major traffic flows, for which they cater, run along these corridors. For example, if one travels west from London by rail from Paddington or by road along the M4 one travels initially through or past Slough and Maidenhead and then to Reading. Other routes might possibly avoid these urban areas but would not be used by so many people. Moreover, the situation is accentuated by the way in which motorways have been used to define planning boundaries for urban development. So, on this western route out of London the M4 is used to define the southern boundary of Slough and then Maidenhead and then the southern boundary of Reading. Thus the planning system allows urban development along one side of the motorway, and then prevents it on the other side. Anyone travelling along the motorway therefore perceives a high degree of urban development. Indeed, because of the use of the M4 
as an urban boundary it has been suggested by one developer, whether seriously or not, that the M4 should be diverted to a more southerly route so that more land to the south of Reading could be used for development!

The third, and I think the main, reason why people believe that the South East is more developed than in fact it is, is because of their perception of space. One has to distinguish between distance on the ground and the time spent travelling that distance. As people travel out of their towns and cities and through the country, what they perceive for most of the time is an urban area because travel in urban areas is slower than travel through rural areas. If you drive across the South East, more than half the time would be spent travelling in an urban area. When I travelled to Cambridge from London to give the Denman Lecture, the journey took about an hour and a quarter, but approximately half an hour was spent getting out of the London suburbs and getting in through the Cambridge suburbs. Only three-quarters of an hour was spent on the motorway travelling the intervening distance through rural areas. But more than 60 per cent of the journey was through rural areas-indeed the proportion was probably nearer 90 per cent. It seems to me that people have in effect a time map, a mental map with time, not distance, contours. Even though perhaps less than 20 per cent of the land across which one travels may be urbanised, because travel is slower through urban areas it may take more than half the time and therefore people perceive that the area through which they travel is more urbanised than it is.

The fourth reason why people perceive the pressure from development to be greater than it is, is because of the way the planning system concentrates applications for development into particular areas. This is very evident in the vicinity of Reading. To the west of Reading and to its north there is an Area of Outstanding Natural Beauty, the North Wessex Downs running into the Chilterns. Every developer knows that he will not get permission for any major development in this area. To the east of Reading, in east Berkshire, is London's green belt and every developer knows that there is very little chance of obtaining permission for development in any area that is designated as green belt. Thus in Berkshire the area where one is most likely to obtain permission for development is central Berkshire, south of Reading. To the south of this, in north-east Hampshire, where there has also been considerable pressure for urban development in the past, the area is also bounded by green belt to the east. Then again to the south of this there are the Surrey hills and the North Downs, both Areas of Outstanding Natural Beauty, so that once again the area where development might occur is highly bounded. To the west and southwest of London, therefore, the number of locations where one might get permission for development is rather small. The result is that the applications for development are concentrated into these areas, which, because they are not green belt and not Areas of Outstanding Natural Beauty, are where most of the existing population live anyway. Therefore the population perceives that there is considerable pressure for development in the area around them, and they assume that there is a similar pressure for development over the whole of the rest of the region.

Finally, the fifth reason why people believe the 'myth of over-development' is that this view is propagated by the agricultural and rural interests. After all, if people living in the towns and cities hear the rural residents talking about "preserving the remnants of the countryside", or preserving "two fields behind our house in order that future generations may know what a field looks like", then the urban population, presuming the rural population to know something at least about the countryside, are likely to accept their argument that the countryside is under the threat of total destruction. 


\section{The Agricultural and Rural Interests}

There are two alternative theories of economic regulation. The first, which derives from Pigou, holds that economic regulation should be designed to ensure the maximisation of human economic welfare so that policies are implemented to balance the social costs and social benefits of their consequences. If this 'public interest' view of British town planning were correct then the restraints on development would reflect the fact that in the view of the population the social costs of further development would exceed the social benefits.

An alternative view of economic regulation was put forward by George Stigler and Richard Posner in the early 1970s (Stigler, 1971; Posner, 1974). According to this view economic interests seek economic regulation of a kind which benefits them, and that where there is any kind of regulation it is necessary to see who the regulation benefits in order to appreciate in whose interest the system of regulation might have been set up. If we take this view and look at who benefits from the planning system, then it could be argued that the system derives from and benefits the interests of those working in agriculture or living in rural areas. A substantial body of evidence would support this view. The public interest view that we have just discussed would argue that the planning system is trying to balance the preservation of the rural environment against the costs involved in increased development in rural areas which could affect the environment. Yet the planning system is not set up to protect the countryside. Almost the reverse is true. There is certainly a case to argue that in fact it is set up almost at the behest or to protect the position of the agricultural and rural interests, and this is not the same thing as protecting the countryside. After all, the Town and Country Planning Acts do not actually apply to agricultural development. You can set up farm buildings-develop piggeries or construct corru- gated iron barns or any buildings which are necessary to agricultural purposes-without obtaining planning permission. In other words you can put up the most 'monstrous carbuncle' in the countryside without planning permission. What you cannot do is put up a house, even though the house may look considerably better than the corrugated iron shed which might otherwise stand in its place.

Moreover the lack of planning control over rural development would appear part of a general policy which allows rural change and prevents urban change. Even though the population may favour the preservation of the rural environment, many farming activities that alter the countryside, for example stripping out hedges, have been subsidised and generally encouraged. Bowers and Cheshire have documented the way in which agricultural policy has actually led to the deterioration of the rural environment (Bowers and Cheshire, 1983). Even now, when agriculture is in surplus, and when the possibility of setting aside land from agricultural use is being seriously discussed, there are virtually no planning controls on agricultural development. If you stop to think about it this is really a rather odd situation. Despite a general view that the Town and Country Planning Acts are meant to preserve the rural environment, agricultural development is uncontrolled. The Acts are designed to control development in urban areas, and to prevent urban development in rural areas, but to leave development by existing rural interests uncontrolled.

It should also be noted that the rural interest which benefits from this situation has changed over the years. In the 1940s there was an overwhelming national need to increase agricultural output, but over the years two changes have occurred. Firstly, there has been a massive increase in agricultural output. In view of this it does not seem to be at all necessary to encourage further increases in agricultural output which may merely be stocked by the European Community and eventually 
dumped. Secondly, the character of the rural population has changed. The number of people employed in agriculture has fallen drastically, from approximately 10 per cent of the working population in 1947 to about 2-3 per cent now. Thus as transport costs have fallen and incomes have increased, there has been a change in the character of village life as middleincome commuters and second home owners have moved in. The villages have been gentrified; demand by commuters and second home owners has been for a nice house in a pretty village. Often two labourers' cottages have been put together to form one of a size regarded as adequate. In consequence the demand for this rural housing has increased while the supply has been restricted, so that house prices in these villages have risen and houses have become too expensive for lower-income households. Indeed, recent reports talk of a considerable rural housing shortage. As this rural housing has become too expensive for lower-income households the local employees have been forced to commute from housing estates providing cheaper housing in nearby towns. At one extreme some local inhabitants in Wales have responded by fire-bombing the homes of English second home owners whom they regard as interlopers. And elsewhere, in England, the newcomers, the gentrifiers, the Mrs Snells of Ambridge, have been those most fiercely opposed to any new development which might spoil the amenity in which they have invested through their purchase of a house in the country.

As an aside one might ask why there is so much opposition to the idea of permitting individual houses in the country. I discussed this once with Professor Patsy Healey, formerly of Oxford Polytechnic and now at the University of Newcastle, and who has therefore been involved with two of the largest schools of town planning in the country. In her view it was not a planning policy that was taught in planning schools. It seemed to be something that students, having graduated, absorbed 'on the job', and both she and I wondered why this view was so ingrained.

To my mind it seems to be a question of aesthetics. Yet it does not seem to accord with any romantic vision of the English countryside as wilderness. After all the English countryside is certainly man-made and could even be described in some cases as hand-made, but it is certainly not a wilderness. Nor does the ideal English landscape exclude buildings if one views this as exemplified in English landscape paintings. Since I started thinking about this problem and looking closely at landscape paintings, it has seemed to me the reverse is true. One always sees a dwelling in a picture, usually at some focal point. The aesthetic criteria therefore seem to be that there actually should be a dwelling in the view in order to improve it. Yet we still seek to exclude isolated dwellings. In the end I concluded that the aesthetic criteria being obeyed were those of the English landscape gardener. We see it in the way the English landowner in the 18th century demolished the village adjacent to the manor house in order to create a park around his house. The villagers, be it noted, did not have any say in the matter. Their views did not count. The idea was to create an empty landscape around the owner's house, although some ruin, grotto or temple might be constructed to provide a focus for the view, but without inhabitants.

Finally, one should note that there is a paradox in that although the English seem to be so against housing in rural areas in England they seem quite happy to accept the idea in other countries. The English will go to Tuscany on holiday or to live. They will find that it is rather difficult to find a location anywhere without a house in the view and yet still regard the Tuscan landscape as beautiful. They might go to Switzerland where they would find, scattered across the mountainside, both houses and villages and yet still regard the Swiss landscape as beautiful. I am not quite clear why what is apparently beautiful elsewhere 
is worth paying an enormous price to avoid in this country.

\section{Political Imbalance}

The views of the agricultural and rural interests, and indeed the views of existing urban dwellers, would not be effective in preventing development if it were not for the political situation and the way the planning system operates. The position with respect to any proposed development is that the existing residents have votes, and can put pressure on their local authority to refuse permission for the development. If it goes to appeal then they can put pressure on the Secretary of State to call it in and reject it. They can exert this pressure through their councillors and Members of Parliament, and in various ways, and their view that the proposed development will affect them in a negative way will therefore carry considerable weight. But the views of the people who might benefit from the development carry little weight. Newcomers do not have votes; the people who might move into the development are unidentified and almost unrepresented. They are represented at the enquiry only by the developer and by the owners of the land who seek permission for the houses to be built for them, who can be represented as acting solely from motives of greed and intending to destroy the environment for the sake of a quick buck. The political system therefore does not actually balance the advantages and disadvantages of development in the way that the public interest theory of economic regulation suggests. The political system always favours the existing residents.

To illustrate what I mean by this, suppose one took an existing village, perhaps one which was a Conservation Area, and considered what would happen if it was proposed that this village should be demolished in order to create an unspoilt piece of English landscape. Clearly there would be an uproar and the residents of the existing village would be leading a campaign against this proposal on the grounds that their village was attractive and that they liked living there, etc. Now suppose this village had never existed, and it was proposed that such a village should now be built; then the residents who, if the village existed, would be leading the battle to retain it, would not now be identifiable. The only people represented in any inquiry would be those who lived nearby. They, of course, would be against the ruination of this unspoilt piece of English countryside, etc. even if what was proposed was as attractive as a village in a Conservation Area. The nearby residents would perceive it, nevertheless, as resulting in a reduction in the quality of their environment. Thus there is an imbalance-the situation is always in favour of the status quo.

Of course to some extent the imbalance results from pure conservatism. Take, for example, the situation with regard to the Settle viaduct in North Yorkshire. At the moment there is a proposal that this rail viaduct across a valley in North Yorkshire might be demolished. As a result there exists a group pressing to retain this viaduct as an attractive feature of the valley. But can you imagine what the situation would have been if in fact there had been no viaduct and British Rail was proposing to build a new one across the valley? It does not need much imagination to believe that the result would have been considerable pressure, indeed uproar, and protests about the invasion of one of the last unspoilt valleys in northern England by an intrusive piece of industrial engineering, etc.

Curiously enough, I have only come across one recent case where the idea of unspoilt English countryside was pursued to its logical conclusion, i.e. the demolition of an existing building. A lady in Yorkshire demolished a house adjacent to hers, because she said it spoilt her view. An interesting feature of this case is that Shelter, the housing charity and pressure group, protested about the loss of a house. It occurred to me to wonder why Shelter 
did not complain, has not complained, and is not on record as complaining, about the various planning refusals of rather more substantial amounts of housing around the country. After all every planning refusal results in a house which is not being built and in some way increases the price of housing. It seems to me that logically Shelter should also be complaining about planning refusals, since these also reduce the quantity of housing available.

Now bearing in mind that newcomers do not have votes, it is worth looking at the way in which the planning system operates and what the consequences are in respect of the form that development takes. With each proposal for development the residents of the local area attempt to create a coalition to block that development, and as we have indicated the position of the incomers, the possible newcomers, is so weak politically that it is probable that if it were left to the lowest level of local authorities there would be little new development because each proposal would be blocked at the local level. Because of this the Department of the Environment formulates proposals as to how many new dwellings are going to be needed in the future to accommodate the new households. Having calculated the number of households likely to exist the Department tells each local authority how many dwellings have to be built in its area. What then happens is that local authorities attempt to minimise the opposition to the amount of development which they are going to have to allow, and this alters the form of development.

I would suggest that there are at least three ways in which the requirement that local authorities build a certain number of dwellings interacts with the way in which pressure groups operate to try and block development, each of which creates a situation in which the new built environment is rather worse for those who move in to the new housing than it otherwise might be. The first of these I call Sardines after the children's game. That game, you may remember, involves trying to pack as many people as possible into a given space.

What happens in the planning version of Sardines is that the local authority, because it realises that any expansion of the area of development will be opposed, tries to minimise the extent of the opposition by limiting the area of land over which development occurs, and it can only do this, and still accommodate the numbers the Department requires, by increasing the density of development on the sites which have been zoned for development. Thus the local authority, if asked to provide more dwellings by the Department, responds by simply increasing the density of development on the sites which have been zoned for development. The high demand for housing means this is economically feasible. The new residents have costs imposed upon them because they are living at a higher density than they would otherwise want to; on the other hand, the existing residents will accept the situation because the development is concentrated into a particular location and not spread around, whilst of course complaining about the nature of the urban development and expressing their determination to prevent any further development of that kind.

Along with this we have the second situation, which I call Eeyore's Gloomy Place. Eeyore's Gloomy Place, you may remember from the stories of Winnie the Pooh, was a dark and boggy corner of the forest. In the planning version a rather poor area of land which is not highly regarded by anyone in the area becomes the most likely site for development, for if it is developed relatively few people will object. Indeed the worse the site environmentally, the less likely it is that development will be opposed by the existing residents. It follows that, since the local authority has to zone some land for residential development in response to the Department's demands, the answer to its problem is to zone sites for development where the environment is rather poor. $A$ favourite is land next to the railway or 
between the railway and a main road. No one is going to object very strenuously to such a site being developed. The fact that the environment for those who move in is rather poorer than it might have been if the development had been located somewhere else if of course immaterial because, as I have indicated, newcomers do not have votes, and the object is to minimise the objections of existing residents.

The third case I call The Faustian Pact. In planning terms this is a pact between one large developer and a local authority to put up one very large, high-density development. This large development will provide in one single location all, or virtually all, the housing which the local authority has been enjoined by the Department to provide in its area. In this way the local authority can solve its problems with minimal political opposition, because once this single development has been steered through, then, if there are any future planning applications for development in the area, the local authority can oppose them by using the argument that no more housing is needed because all that is necessary, as requested by the Department, has been provided in this single development. Thus the local authority is happy: it needs to zone no more land and it can oppose, on behalf of existing residents, all future proposals for development. The developer and the owner of the land are happy because, having negotiated one large, high-density development on th site, both make a considerable profit. And finally the local authority will be even happier if the land which is developed is land owned by the local authority. Of course the new residents might have preferred to live in a better environment than given on a large housing estate. They might have preferred something else-but then they do not have votes. And of course the residents of the commuter villages round about who do have votes are extremely happy because the local authority is resisting development pressures on their behalf, and they will, of course, regard this new, large, high-density development as precisely the sort of thing they are opposing.

\section{Conclusions}

I shall now try to draw together the threads of this discussion. There has been an increased demand for land and housing because of an increasing population, an increasing number of households, rising incomes and the tax advantages of owneroccupation. There has been a restricted supply of land for housing, and I have argued that there appear to be three reasons for this. Firstly, the British population believe it is necessary. They do not recognise the social costs and, in my view, overestimate the extent of urban development. The second reason is that the existing situation is approved by the agricultural and rural interests which it serves. Finally, and most importantly, there is an imbalance in the political system, which results in the existing residents being able to protect their environment, whilst possible new residents do not have votes. The consequence is the description of recent urban development as comprising the construction of 'rabbit hutches on postage stamps', the term I have used in the title. ${ }^{1}$

All this seems paradoxical if you consider the aims of the founders of town planning in this country. Their idea of town planning was to get people out of the cities and into more rural areas where they would have space to live and to breathe; that people should have houses and gardens and live in garden cities. In the late 20 th century it would seem that the aim of town planning is to try and push people back into the cities. But is this really what we want?

Of course, in this paper I have only really dealt with the situation as regards residential development. Development restrictions have also affected industrial and commercial development. There have also been macro-economic consequences. The high price of land for industry results in deindustrialisation, particularly in south- 
ern England. Rising house prices and high land prices result in low levels of saving and push up the rate of inflation, a process which has been investigated by John Muellbauer and his colleagues (Bover et al., 1989). The high price of housing in this country has caused many people to import housing services by buying homes, particularly second homes, abroad. This has been very noticeable in the last few years as people in southern England have tried to buy houses in France, where house prices are half those in southern England. This results in the export of capital which might possibly be better invested in this country. Finally, the high price of land and housing means that obtaining planning permission is itself financially profitable. This results in what economists call 'rent seeking expenditure' as developers spend money trying to obtain planning permission. This expenditure results in no useful economic benefit; as far as the economic system is concerned, it is a deadweight loss.

Now, how do we deal with this situation; what can be done? The suggestion that I made in the Institute of Economic Affairs paper No Room! No Room! (Evans, 1988) was that it might be possible to allow the developers to make what economists call 'side payments' to compensate objectors. If the objectors feel that they are suffering from the proposed development then they could be compensated, with an agreement being reached in which compensation is paid for the reduction in the quality of their environment. Unfortunately this looks a little like bribery and for that reason this solution would probably not be acceptable. Nevertheless some move in this direction has occurred with the spread of planning gain agreements by which, if they obtain permission, developers agree to provide or pay for various amenities which may benefit local residents. The fact that compensation might work is indicated by an example I came across recently in Kenton, in north-west London. For some years Sainsbury's has been trying to build a supermarket there against strong opposi- tion by local residents. Only the week before the delivery of the Denman Lecture it was announced that some local residents had agreed terms with Sainsbury's whereby the firm would buy their homes at a price 20 per cent above the market value in order, allegedly, to provide increased car parking space, and it was reported that the local home owners were deciding whether this would mean that they would support the Sainsbury's proposal. In other words, if the price was high enough to compensate them for having to move they would be willing to move and also to support the proposed development.

A second possibility is that there might be a firmer lead from the centre, from the Department of the Environment, directing local authorities to increase the supply of land. However, I regard this as politically unlikely because the Department is now bidding for the green vote. Paradoxically, of course it seems odd that rural land is regarded as better ecologically than back gardens, because in fact the way in which the modern farmer farms the land results in monoculture-the only thing that is allowed to be grown in the field is the single product which it is intended should be grown. Pesticides, insecticides, fungicides, etc. are used to eliminate all other vegetation and animal life. If you want to find frogs you are more likely to find them in back gardens in suburbs than in the country and the intensive development of agricultural land is one reason why, for example, foxes and magpies have been moving into the suburbs. The countryside is more hostile to wildlife.

A third possibility is to attempt to reduce the demand for housing. This demand is artificially inflated. As I indicated at the beginning, a major reason for the increased demand for housing is the extent of the tax advantages of owner-occupation, and it is worthwhile listing what the tax advantages are. There is mortgage interest relief on loans up to $£ 30000$; there is no tax on what economists would call the imputed income from the investment in 
housing-Schedule A, which was such a tax, was abolished in 1961; there is no value added tax on housing (except on extensions); there is no capital gains tax on housing; and finally, since 1 April 1990 in England and Wales (and 1 April 1989 in Scotland) there have been no rates on housing. The sole change in the tax system which might result in a reduction in the demand for housing is the double community charge on second homes, but then even this may simply result in people being more likely to buy their homes in France. Now, to put it no more strongly, it seems paradoxical that on the one hand we have a planning system which many people believe is aiming correctly to restrict the amount of land which is used for housing, while, on the other hand, we have a tax system which encourages people to spend money on housing. So we restrict supply and we increase demand. Now it is virtually self-evident that these incentives which increase demand, given the supply restrictions, merely result in increased house prices. (The argument one has heard recently that because of high house prices mortgage interest relief should be increased would indicate that some people believe that fires can be fought by pouring oil on them.)

If asked whether I anticipate any change in the situation in the $1990 \mathrm{~s}$, pessimistically I have to answer that I do not. The 1990 s will re-run the 1980 s; the housing market will be depressed for 2 or 3 years, and everyone will believe that the only problem is that of stimulating the demand for housing. Somewhere around 1992 a new boom will start and a year or so after that people will begin to worry about the availability of housing. There may be some sort of rethink of the position towards the end of that boom in 1995-96 but I am afraid that when that boom ends the problem will once again be forgotten.

\section{Note}

1. Giving credit where it is due, the phrase originated with Lord Northfield, Chairman of Consortium Developments Ltd.

\section{References}

Ball, M. (1983) Housing Policy and Economic Power. London: Methuen.

BEST, R.H. (1981) Land Use and Living Space. London: Methuen.

Bover, O., Muellbauer, J. and Murphy, A. (1989) Housing, wages and UK labour markets, Oxford Bulletin of Economics and Statistics, 51, pp. 97-136.

BOWERS, J.K. and Cheshire, P. (1983) Agriculture, the Countryside and Land Use: An Economic Critique. London: Methuen.

Cheshire, P. and Sheppard, S. (1989) British planning policy and access to housing: some empirical estimates, Urban Studies, 26, pp. 469-485.

Evans, A.W. (1973) The Economics of Residential Location. London: Macmillan.

Evans, A.W. (1985) Urban Economics. Oxford: Basil Blackwell.

Evans, A.W. (1987) House Prices and Land Prices in the South East-A Review. London: The Housebuilders Federation.

Evans, A.W. (1988) No Room! No Room! London: Institute of Economic Affairs.

Harrow Observer (1989) 16 March, p. 9.

HOUSE OF COMMONS (1983) Green Belt and Land for Housing: Appendices, First Report from the Environment Committee, Session 1983-84. HC 275. London: HMSO.

National House-BuILDing COUNCIL (1990) Private House Building Statistics. London: National House-building Council.

PoSNER, R.A. (1974) Theories of economic regulation, Bell Journal of Economics and Management Science, 5, pp. 335-358.

STIGLER, G.J. (1973) The theory of economic regulation, Bell Journal of Economics and Management Science, 2, pp. 3-21.

TYM, R. \& PARTNERS (1987) Land Used for Residential Development in the South East: Summary Report. London: Roger Tym \& Partners. 